\title{
The Effect of Albendazole Administration and Iron-Folic Acid Supplementation on Hemoglobin Level in Primary Schoolchildren with Soil-transmitted Helminth Infections
}

\author{
Willhans Wijaya, Ayodhia Pitaloka Pasaribu*, Erwin Suteno, Nirmala Husin, Syahril Pasaribu \\ Department of Child Health, Faculty of Medicine, Universitas Sumatera Utara, Medan, Indonesia
}

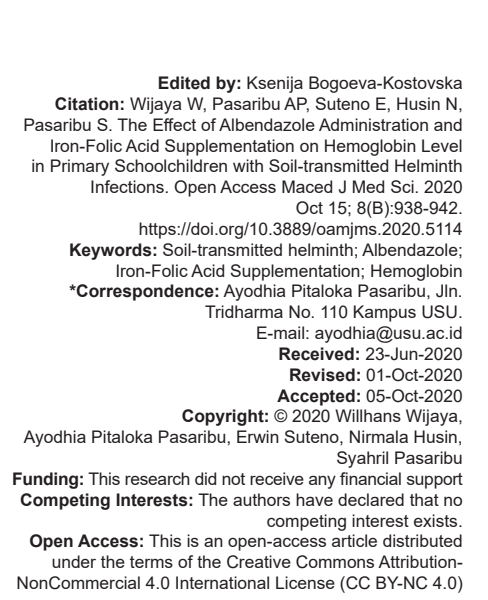

\begin{abstract}
BACKGROUND: Soil-transmitted helminth (STH) infections were the highest infection in children aged 5-15 years old. They lead to iron deficiency anemia and folic acid deficiency. One of the strategies to treat the issues is anthelmintic administration with iron-folic acid supplementation.

AIM: This study aims to evaluate the effectiveness of single-dose albendazole and albendazole with iron-folic acid supplementation on hemoglobin $(\mathrm{Hb})$ levels in children with STHs.

METHODS: This was an open-label randomized clinical trial conducted in Batubara Regency from September to November 2018. Subjects were primary schoolchildren with STH infections. They were grouped into albendazole and albendazole with iron-folic acid supplementation groups. The data were analyzed by independent t-test and Mann-Whitney U-test.

RESULTS: From 139 children, 72 children received albendazole single dose and 67 children received albendazole with $30 \mathrm{mg}$ iron and $250 \mu \mathrm{g}$ folic acid weekly for 3 months. The median of baseline hemoglobin level was $12.2 \mathrm{gr} / \mathrm{dL}$, whereas after intervention was $12.7 \mathrm{gr} / \mathrm{dL}$. The hemoglobin level increases did not differ significantly between the two groups $(p>0.05)$. However, clinical improvement was observed.
\end{abstract}

CONCLUSION: Iron-folic acid supplementation in addition to albendazole did not show any benefit for primary schoolchildren with STH infection in Batubara Regency, North Sumatera, Indonesia.

\section{Introduction}

Soil-transmitted helminths (STHs) are groups of nematode worms which cause infections in humans through contacts with soil that contain worm eggs or larvae. In general, STH infections are caused by roundworms (Ascaris lumbricoides), whipworms (Trichuris trichiura), threadworms (Strongyloides stercoralis), and hookworms (Ancylostoma duodenale and Necator americanus) [1], [2], [3], [4].

The research done by Pasaribu (2004) in Suka Village, TigaPanah district, Karo Regency, North Sumatra, Indonesia, showed that the prevalence of helminthiasis in schoolchildren was $91.3 \%$ [5]. The performance accountability report of North Sumatra government health agency (2012) stated that the prevalence of STH infections in primary schoolchildren was $32.3 \%$, with the distribution of $A$. lumbricoides and $T$. trichiura and hookworms species at $21 \%$, $11 \%$, and $0 \%$, respectively [6]. Another study done by Jiero et al. (2015) in Medan, Belawan, North Sumatra in two primary schools showed $65.4 \%$ prevalence of STH infections [7]. The provided data have shown that helminthiasis cases are still high in schoolchildren, especially in North Sumatra.

STH infections mainly occur in children living in slums where sanitation is inadequate, population is dense, education levels are low, and health facilities are lacking. World Bank stated STH infections as the most found cases of infections in children aged 5-15 years old [8]. The long-term effects of STH infections can affect nutritional status in children, performance in schools, and long-term cognitive development. Iron status is assumed to be the intermediary for the occurrence of those effects. Hookworm and whipworm infections are related to iron deficiency anemia which lead to the decrease of physical activity and work productivity. Besides that, STH infections also cause micronutrient deficiencies, one of them is folic acid [8], [9].

Hookworm infection is the main cause of anemia and iron deficiency in children. They depend on several factors such as the species and quantity of worms, the length of infections, iron deposits in the body, food intake and absorption, and the physiology of iron needs. Mild hookworm infection may cause anemia in individuals with low iron intake and stores in the body. A. duodenale infection is less common but it causes 
higher blood loss than $N$. americanus infection. Adult worms attach to host's intestinal mucosa and ingest food from there. This is the main cause of blood loss from the intestines that lead to iron deficiency and anemia. Besides the habit of feeding on blood, hookworms also release anti-clotting factor that makes blood excreted continuously. A. duodenale causes 2-10 times more blood loss compared to $N$. americanus [10], [11].

A. lumbricoides worm infection is known to affect the nutritional status in infected children. However, the mechanism of anemia is not known clearly. The research done by Osazuwa et al. (2011) in Nigeria showed a significant correlation between A. lumbricoides infection and anemia [11]. Around 1 billion of school-age children in the world were estimated to be infected with at least one type of STH. While, around 600 million of pre-schools and schoolchildren were estimated to suffer from anemia. Half of those cases were caused by iron deficiency [12].

Iron supplementation aims to prevent anemia and treat iron deficiency before iron deficiency anemia occurs. The strategy for supplementation and food intake to increase iron stores is recommended in the population with risks of anemia and iron deficiency. Once a week iron and folic acid supplementation effectively increases iron stores [13], [14]. Besides that, the WHO recommends deworming strategy, in which anthelmintic is given to control the morbidity due to STH infections in high-risk populations. Anthelmintic drugs intervened to control STH infections are albendazole, mebendazole, levamisole, and pyrantel pamoate [15]. The study in India by Bhoite and lyer (2012) showed that the supplementation of iron and folic acid in deworming program to schoolchildren led to effective hemoglobin increases [16].

This study aims to compare the efficacy of anthelmintic drug administration, which is albendazole due to its work mechanisms as larvicidal, ovicidal, and vermicidal [17], followed by the supplementation of iron plus folic acid to increase $\mathrm{Hb}$ levels in schoolchildren with STH infections.

\section{Methods}

This study was an open-label randomized clinical trial conducted in SD Negeri 014734 Labuhan Ruku, SD Negeri 014740 Pahang, and SD Negeri 010157 Sei Muka in Talawi, Batubara Regency, North Sumatra. The study was done from September to November 2018. Samples that met inclusion and exclusion criteria were selected by simple random sampling. Inclusion criteria were schoolchildren in primary education level $\mathrm{I}-\mathrm{VI}$, with one or combined STH infections such as $A$. lumbricoides, $T$. trichiura, A. duodenale, or $N$. americanus based on Kato-Katz analysis, no consumption of other anthelmintic drugs in $\leq 1$ month and iron and folic acid in the past 3 months before the study. Exclusion criteria were all children who did not follow the study procedures such as blood sampling and feces collection and have been previously diagnosed, or through anamnesis and physical examination, with chronic diseases.

All parents and guardians were informed about the study and consent was received before joining the study. Feces were collected and examined by Kato-Katz method. Children with positive results of helminthiasis were divided into two groups and $\mathrm{Hb}$ level test was done to the children. The first group received albendazole $400 \mathrm{mg}$ as a single dose, while the second group received albendazole $400 \mathrm{mg}$ together with weekly administration of iron $30 \mathrm{mg}$ and folic acid $250 \mu \mathrm{g}$ for 3 months. Feces and $\mathrm{Hb}$ level tests were repeated after 3 months. Hb level was measured using HemoCue $\mathrm{Hb} 301$.

\section{Data analysis}

Data analysis was done using computerized system SPSS version 22, with 95\% confidence interval (Cl) and significance level of $p<0.05$. Data from both groups were analyzed using Chi-square and MannWhitney analyses to compare STH infections and $\mathrm{Hb}$ levels, respectively.

\section{Ethical considerations}

This study was approved by Health Research Ethics Committee, Medical Faculty, Universitas Sumatera Utara (No.01/TGL/KEPK FK USU-RSUP HAM/2018).

\section{Results}

\section{Characteristic data of research subjects}

In this study, feces examination was done to 384 children from primary education level I to VI. Based on the inclusion and exclusion criteria, 139 children with STH infections were involved in this research and they were divided into two groups. The first group consisted of 72 children and they received albendazole $400 \mathrm{mg}$ tablet therapy as a single dose, whereas the second group consisted of 67 children who received albendazole $400 \mathrm{mg}$ tablet therapy with weekly supplementation of iron $30 \mathrm{mg}$ and folic acid $250 \mu \mathrm{g}$ for 3 months. The consort flow diagram for the overall procedures is shown in Figure 1.

Most STH infections found were $T$. trichiura type of worms. STH infection mostly occurred in children at the age of 5-13 years old, with more male children 


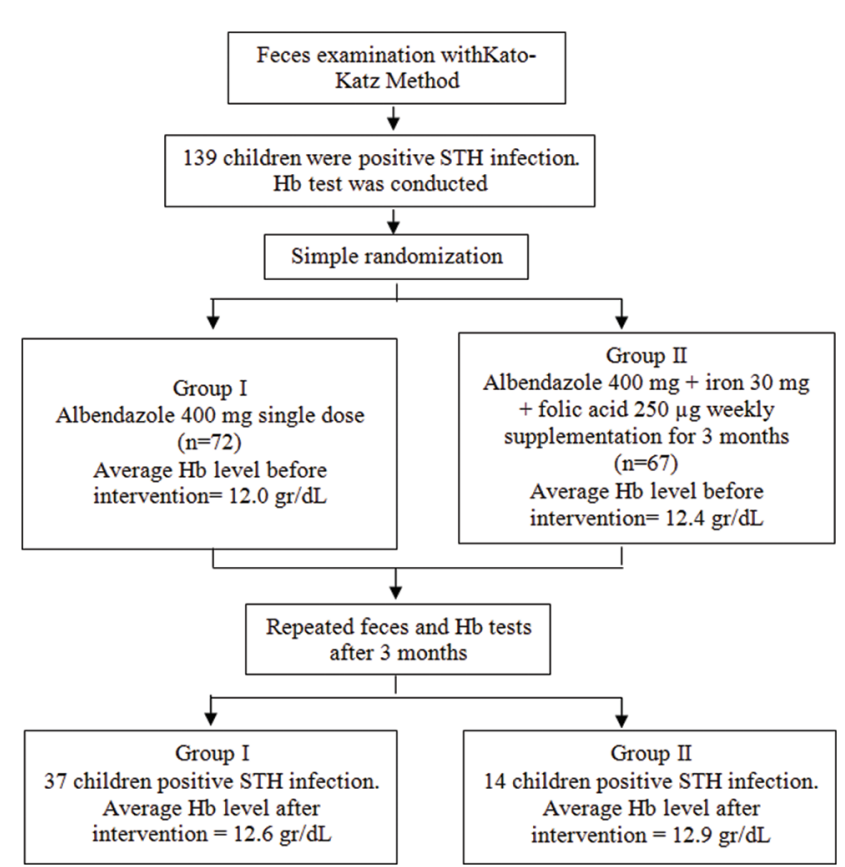

Figure 1: Consort flow diagram

than female's in both groups, where $56.9 \%$ of male and $43.1 \%$ of female in Group I while $53.7 \%$ of male and $46.3 \%$ of female in Group II. The average age of the two groups was 9 years old. The majority of children with STH infections were recorded to have good nutritional status. The distribution of subject characteristics data is shown in Table 1.

Table 1: Subject characteristics data distribution

\begin{tabular}{lll}
\hline Characteristic & $\begin{array}{l}\text { Group I } \\
(\mathrm{n}=72)\end{array}$ & $\begin{array}{l}\text { Group II } \\
(\mathrm{n}=67)\end{array}$ \\
\hline Gender, $\mathrm{n}(\%)$ & $41(56.9)$ & $36(53.7)$ \\
$\quad$ Male & $31(43.1)$ & $31(46.3)$ \\
$\quad$ Female & $9(5-13)$ & $9(6-12)$ \\
Age, years old Median (range) & $22(14-61)$ & $22(17-39)$ \\
Weight, kg Median (range) & $123.3(10.8)$ & $124.9(8.9)$ \\
Height, cm Average (SD) & & \\
Nutritional status, $\mathrm{n}(\%)$ & $24(33.3)$ & $10(14.9)$ \\
$\quad$ Undernutrition & $40(55.6)$ & $53(79.1)$ \\
$\quad$ Good nutrition & $8(11.1)$ & $4(6.0)$ \\
$\quad$ Overnutrition & & \\
STH infections, $\mathrm{n}(\%)$ & $20(27.8)$ & $11(16.4)$ \\
$\quad$ A. lumbricoides & $65(90.3)$ & $57(85.1)$ \\
$\quad T$. trichiura & $0(0)$ & $1(1.5)$ \\
$\quad$ Hookworm & & \\
Eggs/gram feces, epg & & \\
Geometric mean (SD) & $2395.5(5.87)$ & $95.5(13.73)$ \\
$\quad$ A. lumbricoides & $282.0(4.24)$ & $107.6(2.31)$ \\
$\quad$ T. trichiura & $0(0)$ & $648(648)$ \\
$\quad$ Hookworm & $12.0(10.1-13.2)$ & $12.4(9.9-15.1)$ \\
Hemoglobin level before intervention, gr/dL & & \\
Median (range) & &
\end{tabular}

\section{Comparison of soil-transmitted helminth infections before and after intervention}

The prevalence of helminthiasis in this study conducted in Talawi, Batubara Regency, North Sumatra, was $36.2 \%$ (139/384). The most found worm infections were T. trichiura at $31.8 \%(122 / 384)$ followed by A. lumbricoides and hookworm at $8.1 \%(31 / 384)$ and $0.5 \%$ (1/384), respectively. The intensity of $A$. lumbricoides and $T$. trichiura worm infections was mild to moderate, while hookworm infection was at mild intensity.
There were 123 children with single STH infections while 16 children had two types of worm infections. The overall prevalence of STH infections dropped after albendazole therapy to $13.3 \%(51 / 384)$ with $A$. lumbricoides and $T$. trichiura infections become $1.3 \%(5 / 384)$ and $12.8 \%(49 / 384)$, respectively. There was an increase of hookworm infection prevalence to $0.5 \%$ (2/384). These data are presented in Table 2. The prevalence was decreased in both groups after the intervention for both $A$. lumbricoides and T. trichiura infections. There were no significant differences statistically in both groups after the intervention.

Table 2: The comparison of STH infections before and after intervention

\begin{tabular}{lll}
\hline Variable & $\begin{array}{l}\text { Before albendazole } \\
\text { administration } \mathrm{n}(\%)\end{array}$ & $\begin{array}{l}\text { After albendazole } \\
\text { administration } \mathrm{n}(\%)\end{array}$ \\
\hline STH infection, & $31(8.1)$ & $5(1.3)$ \\
$\quad \begin{array}{l}\text { A. lumbricoides } \\
\text { T. trichiura }\end{array}$ & $122(31.8)$ & $49(12.8)$ \\
$\quad$ Hookworm & $1(0.3)$ & $2(0.5)$ \\
Intensity of A. lumbricoides infection & & \\
$\quad$ Mild & $24(6.3)$ & $3(0.8)$ \\
$\quad$ Moderate & $7(1.8)$ & $2(0.5)$ \\
Intensity of T. trichiura infection & & \\
$\quad$ Mild & $107(27.9)$ & $47(12.2)$ \\
$\quad$ Moderate & $15(3.9)$ & $2(0.5)$ \\
Intensity of hookworm infection & & \\
$\quad$ Mild & $1(0.3)$ & $2(0.5)$ \\
$\quad$ Moderate & $0(0)$ & $0(0)$ \\
STH single infections & $123(32)$ & $47(12.2)$ \\
Infections with two types of worms & $16(4.2)$ & $4(1)$ \\
\hline
\end{tabular}

\section{Hb level differences after albendazole and} iron-folic acid supplementation

The average $\mathrm{Hb}$ levels of all children before intervention in this study were $12.2 \mathrm{gr} / \mathrm{dL}$ and after intervention were $12.7 \mathrm{gr} / \mathrm{dL}$. The differences between pre- and post-treatment in both groups were statistically significant $(p<0.05)$. However, there were no significant differences $(p<0.05)$ in $\mathrm{Hb}$ level increases between the groups with single dose of albendazole and the group with albendazole and iron-folic acid supplementation treatment (Table 3).

Table 3: Hb level in both research groups

\begin{tabular}{|c|c|c|c|}
\hline Variable & Group I & Group II & $P$ \\
\hline $\begin{array}{l}\mathrm{Hb} \text { level before intervention, } \mathrm{gr} / \mathrm{dL} \\
\text { Median (range) }\end{array}$ & $12.0(10.1-13.2)$ & $12.4(9.9-15.1)$ & $0.020^{\mathrm{a} *}$ \\
\hline $\begin{array}{l}\mathrm{Hb} \text { level after intervention, gr/dL } \\
\text { Median (range) }\end{array}$ & $12.6(10.3-13.6)$ & $12.9(11.5-14.8)$ & $0.010^{a *}$ \\
\hline $\begin{array}{l}\mathrm{Hb} \text { level increases, gr/dL } \\
\text { Median (range) }\end{array}$ & $0.5(-0.5-2.2)$ & $0.3(-2.3-3.3)$ & $0.650^{\mathrm{a}}$ \\
\hline
\end{tabular}

a Mann-Whitney U-test

\section{Discussion}

STH infection is one of the major health problems in developing countries, especially in regions with warm and moist climate where the sanitation and hygiene are poor [18]. Indonesia is one of the countries with tropical climate where STH is suitably developed. The prevalence of STH infection in this study done in 
Talawi, Batubara Regency, North Sumatra, was $36.2 \%$. This result was lower than the previous studies done by Jiero et al. (2015) in Medan, Belawan, North Sumatra and Pasaribu (2019) in Suka Village, TigaPanah district, Karo Regency, North Sumatra, with $57.24 \%$ sample population positive for one or more STH infections. There were $67.91 \%$ of children with single infection, $30.97 \%$ with double infections, and $1.12 \%$ with triple infections [19]. The low prevalence may be due to the helminthiasis control program done by the government targeting pre-schools (1-4 years old) and school-age (5-12 years old) children [20].

This study shows STH infection occurred in children at the age of 5-13 years old. This result was not far different from the previous research done by Jiero et al. (2015) in Belawan that reported cases in children aged 7-13 years old (7), while another study done in Suka Village by Pasaribu (2004) and Pasaribu (2019) showed that children of 5-10 years old had the highest prevalence [5],[19].

There were more male children than female with STH infection cases. A study done by Annisa et al. (2018) in Palembang showed more female children $(51.7 \%)$ with STH infections [21]. The differences in STH infections between male and female were not influenced by gender but lack of personal hygiene factor in children [22].

According to Ahmed et al. (2012) and Cabada et al. (2015), STH infections were correlated to the decrease of appetite and food intake which lead to the decrease of growth, poor physical health, and cognitive functions and even malnutrition in children $[23,24]$. In this study, a big portion of children with STH infections had good nutritional status. This result aligns with the previous study done by Maharani et al. (2015) in Padang where most children with STH infections had good nutritional status and there were no relationships between STH infections and nutritional status observed from body height and weight aspects [25]. However, a research conducted by Simarmata et al. (2015) in Kabanjahe, North Sumatra, showed that most children $(70 \%)$ with STH infections had malnutrition [26]. Several other studies showed a complex relationship between nutritional status and STH infections which are influenced by many factors such as environment, social, and economy status. Moreover, this study showed that most cases were mild degree of infections, while there was a research done showing malnutrition was correlated to moderate and severe STH intensity [27].

The most found worm infections were T. trichiura at $31.8 \%(122 / 384)$ followed by $A$. lumbricoides and hookworm at $8.1 \%(31 / 384)$ and $0.5 \%(1 / 384)$, respectively. The previous studies done by Jiero et al. (2015) in Medan Belawan, Pasaribu (2004) and Pasaribu (2019) in Karo Regency showed A. lumbricoides as the highest infections found [5], [7], [19]. This difference may be due to the treatment for $T$. trichiura infections require repeated doses of albendazole [4], [28], [29]. Although albendazole is a broad-spectrum anthelmintic drug taken orally as a single dose to control intestinal worms, the treatment for $T$. trichiura infections is less effective than to A. lumbricoides and hookworm infections [29]. The study done by Sungkar et al. (2019) showed that the consumption of albendazole for 3 consecutive days was effective to control STH infections [28].

$\mathrm{Hb}$ level increase in this study showed no significant differences statistically between the groups that received albendazole as a single dose and albendazole with iron-folic acid supplementation. However, the study done by Bhoite and lyer (2012) showed that the supplementation of iron and folic acid in deworming program to schoolchildren led to effective hemoglobin increases [16]. These differences were possible because the subjects with anemia in this research were very few and the majority of STH infections were mild.

\section{Conclusion}

In this study, iron-folic acid supplementation in addition to albendazole did not show any benefit for primary schoolchildren with STH infection in Batubara Regency, North Sumatera, Indonesia. Hb levels increase after the administration of albendazole either with or without the supplementation of iron and folic acid. Further research with a larger sample size is needed to observe the supplementation of iron-folic acid in children with STH infections.

\section{References}

1. World Health Organization. Soil-transmitted Helminthiases: Eliminating Soil Transmitted Helminthiases as a Public Health Problem in Children. Progress Report 2001-2010 and Strategic Plan 2011-2020. Geneva, Switzerland: World Health Organization; 2012.

2. World Health Organization. Soil-transmitted helminthiases: Number of children treated in 2014. Wkly Epidemiol Rec. 2015;90(51-52):705-11.

PMid:26685391

3. World Health Organization. Soil-transmitted Helminth Infections; 2016. Available from: http://www.who.int/mediacentre/ factsheets/fs366/en. [Last accessed on 2017 Jan 22].

4. Bethony J, Brooker S, Albonico M, Geiger SM, Loukas A Diemert D, et al. Soil-transmitted helminth infections: Ascariasis, trichuriasis, and hookworm. Lancet. 2006;367(9521):1521-32. https://doi.org/10.1016/s0140-6736(06)68653-4 PMid:16679166

5. Pasaribu S. Determination of Optimal Frequency of Ascariasis Mass Treatment with Albendazole in Elementary School Children in Suka Village, Dissertation. Medan: Postgraduate USU; 2004 
6. North Sumatra Public Health Office. Performance Accountability Report of North Sumatra Public Health Government Agencies Year 2011. Medan: Public Health Office North Sumatra; 2012. p. 22-95. https://doi.org/10.26911/the6thicph.02.27.

7. Jiero S, Ali M, Pasaribu S, Pasaribu AP. Correlation between eosinophil count and soil-transmitted helminth infection in children. Asian Pac J Trop Dis. 2015;5(10):813-6. https://doi. org/10.1016/s2222-1808(15)60936-7

8. Robinson DC, Maayan N, Weiser KS, Donegan S, Garner P. Deworming drugs for soil-transmitted intestinal worms in children: Effects on nutritional indicators, haemoglobin, and school performance. Cochrane Database Syst Rev. 2015;2015(7):CD000371. https://doi.org/10.1002/14651858. CD000371

PMid:26202783

9. Crompton DW, Nesheim MC. Nutritional impact of intestinal helminthiasis during the human life cycle. Annu Rev Nutr. 2002;22:35-59. https://doi.org/10.1146/annurev. nutr.22.120501.134539

PMid:12055337

10. Jonker FA, Calis JC, Phiri K, Brienen EA, Khoffi H, Brabin BJ, et al. Real-time PCR demonstrates Ancylostoma duodenale is a key factor in the etiology of severe anemia and iron deficiency in Malawian pre-school children. PLoS Negl Trop Dis. 2012;6(3):e1555. https://doi.og/10.1371/journal.pntd.0001555 PMid:22514750

11. Osazuwa F, Ayo OM, Imade P. A significant association between intestinal helminth infection and anaemia burden in children in rural communities of Edo state, Nigeria. N Am J Med Sci. 2011;3(1):30-4. https://doi.org/10.4297/najms.2011.330 PMid:22540060

12. Ebenezer R, Gunawardena K, Kumarendran B, Pathmeswaran A, Jukes MC, Drake LJ, et al. Cluster-randomised trial of the impact of school-based deworming and iron supplementation on the cognitive abilities of schoolchildren in Sri Lanka's plantation sector. Trop Med Int Health. 2013;18(8):942-51. https://doi. org/10.111/tmi.12128

PMid:23837404

13. Casey GJ, Phuc TQ, Macgregor L, Montresor A, Mihrshahi S, Thach TD, et al. A free weekly iron-folic acid supplementation and regular deworming program is associated with improved hemoglobin and iron status indicators in Vietnamese women. BMC Public Health. 2009;9:261. https://doi. org/10.1186/1471-2458-9-261

PMid:19630954

14. Casey GJ, Montresor A, Cavalli-Sforza LT, Thu H, Phu LB, Tinh TT, et al. Elimination of iron deficiency anemia and soil transmitted helminth infection: Evidence from a fifty-four month iron-folic acid and de-worming program. PLoS Negl Trop Dis. 2013;7:2146. https://doi.org/10.1371/journal.pntd.0002146 PMid:23593517

15. Keiser J, Utzinger J. Efficacy of current drugs against soiltransmitted helminth infections: Systematic review and metaanalysis. JAMA. 2008;299(16):1937-48. https://doi.org/10.1001/ jama.299.16.1937

PMid:18430913

16. Bhoite RM, lyer UM. Effect of deworming vs iron-folic acid supplementation plus deworming on growth, hemoglobin level, and physical work capacity of school children. Indian Pediatr. 2012;49(8):659-61. https://doi.org/10.1007/s13312-012-0129-y
PMid:22962239

17. Dayan AD. Albendazole, mebendazole and praziquantel Review of non-clinical toxicity and pharmacokinetics. Acta Trop. 2003;86(2-3):141-59. https://doi.org/10.1016/ S0001-706X(03)00031-7

PMid:12745134

18. Centers for Disease Control and Prevention. Parasites-Soiltransmitted Helminths; 2013. Available from: https://www.cdc. gov/parasites/sth. [Last accessed on 2017 Jan 22].

19. Pasaribu AP, Alam A, Sembiring K, Pasaribu S, Setiabudi D. Prevalence and risk factors of soil-transmitted helminthiasis among school children living in an agricultural area of North Sumatera, Indonesia. BMC Public Health. 2019;19:1066. https://doi.org/10.1186/s12889-109-7397-6

PMid:31391023

20. Ministry of Health of the Republic of Indonesia. Deworming Control Guidelines, Ministry of Health of the Republic of Indonesia, Directorate General of PP and PL; 2012. p. 1-38.

21. Annisa S, Dalilah D, Anwar C. The Relationship between soil transmitted helminthes (STH) and nutritional status in primary children of public elementary school 200 (SDN 200) Kemasindo regency, Kertapati district, Palembang. Sriwijaya Med Mag. 2018;50(2):92-104. https://doi.org/10.32539/bsm.v2i2.39.

22. Martila M, Sandy S. Paembonan N. The relationship between personal hygiene and worm infections among students at Abe Pantai Jayapura public elementary school. J Plasma. 2015;1(2):87-96. https://doi.org/10.22435/plasma. v1i2.4538.87-96.

23. Ahmed A, Al-Mekhlafi HM, Al-Adhroey AH, Ithoi I, Abdulsalam AM, Surin J. The nutritional impacts of soiltransmitted helminths infections among orang asli school children in rural Malaysia. Parasit Vectors. 2012;5:119. https:// doi.org/10.1186/1756-3305-5-119

PMid:22704549

24. Cabada M, Goodrich MR, Graham B, Villanueva-Meyer PG Deichsel EL, Lopez M, et al. Prevalence of intestinal helminths, anemia, and malnutrition in Paucartambo Peru. Pan Ame $J$ Public Health. 2015;37(2):69-75.

PMid:25915010

25. Maharani RR, Rusjdi SR, Elmatris SY. The relationship between soil transmitted helminth and nutritional status among students in public elementary school 29 Purus Padang. JKA. 2015;4(2):353-8. https://doi.org/10.2174/1871530320666200427112902

26. Simarmata N, Sembiring T, Ali M. Nutritional status of soiltransmitted helminthiasis infected and uninfected children. Paediatr Indones. 2015;55(3):136-41. https://doi.org/10.14238/ pi55.3.2015.136-41

27. Schaible UE, Kaufmann SH. Malnutrition and infection: Complex mechanisms and global impacts. PLoS Med. 2007;4(115):80612. https://doi.org/10.1371/journal.pmed.0040115 PMid: 17472433

28. Sungkar S, Putri KQ, Taufik MIS, Gozali MN, Sudarmono P. The effectiveness of triple dose albendazole in treating soil transmitted helminths infection. J Parasitol Res. 2019;2019:6438497. https://doi.org/10.1155/2019/6438497 PMid:30863624

29. Lubis $A D$, Pasaribu S, Ali M, Lubis M. Effect of length of albendazole treatment againts Trichuris trichiura infection. Paediatr Indones. 2013;53(5):245-9. https://doi.org/10.14238/ pi53.5.2013.01 